\title{
The Dispute between the Constitutional Tribunal and The Supreme Court OVER INTERPRETATIVE VERDICTS IN The Republic of Poland
}

\author{
Marcin Dąbrowski \\ Faculty of Law and Administration, University of \\ Warmia and Mazury in Olsztyn, Poland \\ m_dabrowski@wp.eu
}

DĄBROWSKI, Marcin. The Dispute between the Constitutional Tribunal and the Supreme Court over Interpretative Verdicts in the Republic of Poland. International and Comparative Law Review, 2017, vol. 17, no. 1, pp. 211-222. DOI 10.2478/iclr-2018-0009.

\begin{abstract}
Summary: The article is focused on a serious dispute between the Supreme Court and the Constitutional Tribunal over interpretative verdicts in the Republic of Poland. This kind of decisions are issued by the Tribunal. Interpretative verdicts contain explanation (interpretation) of a statutory provision, which constitutionality is controlled by the Tribunal. The main problem is, if this kind of decisions bind other courts. Judges of the Tribunal Court claim that courts, including the Supreme Court, are suppose to obey interpretative verdicts. The judges of Supreme Court maintain that this kind of decisions only indicates one of possible interpretation of a statutory provision and courts don't have to follow it. In the article the author describes this type of verdicts, their history and explains the essence of the dispute.
\end{abstract}

Keywords: Constitutional Tribunal, Supreme Court, dispute, interpretative verdict, judgements, The Constitution of the Republic of Poland, interpretation, officially binding interpretation.

\section{Introduction}

Disputes between the Constitutional Tribunal and the Supreme Court have a long tradition. We can even say that they have become part of the legal position of these institutions and permanent tension between them is part of the rule of separation and balance of powers. In this paper I will present an old dispute that has arisen over interpretative judgements delivered by the Tribunal. Some authors claim that these disputes are unresolvable ${ }^{1}$. In particular, the dispute over interpretative judgements is of such a nature. There are so many arguments and they are so sophisticated and complicated that we may say that there is no dialogue, only monologues. Yet the most important is the problem that oppos-

1 Morawski, Lech. Zasady wykładni prawa. Torun: Dom Organizatora TNOiK, 2010, pp. 40. 
ing parties in the dispute do not want to hear reciprocal opinions and that both present important and weighty arguments.

Interpretative judgements refer to the interpretation of laws in accordance with the constitution and the presumption of constitutionality ${ }^{2}$. This is a special method of interpreting legal texts which is used by most of the contemporary constitutional courts ${ }^{3}$. It is part of judicial self-restraint doctrine. This doctrine limits activism of judges and protects a legislator from too serious an impact on its independence and autonomy. A derogation of a legal act or its provision shall be a final solution. A constitutional court should take any possible legal actions to avoid it. The presumption of constitutionality is a legal assumption that all statutes are legal and do not disrupt the constitution. Only constitutional courts are able to rebut the presumption in a special procedure.

Interpretative judgements are kind of decisions of the constitutional court. It is said that this kind of judgments have been taken from German constitutionalism by the Polish Tribunal. ${ }^{4}$ Usually the Tribunal issues uncomplicated (simple) judgements which confirm or negate constitutionality of a statute (or its provision). But sometimes the Tribunal finds that a provision or a statute is correct if it is understood as explained in the conclusion of the judgement. The interpretation of the provision binds as a typical decision. Pursuant to the Article 190.1 'Judgments of the Constitutional Tribunal shall be of universally binding application and shall be final'. An attribute of constitutionality or unconstitutionality relates to a norm reconstructed from a legal text, but it does not result in the derogation of a provision. Because interpretation is part of the conclusion of the judgement, it has its binding force ${ }^{5}$. The Tribunal uses such a construction, because sometimes a provision might be in accordance with the Constitution in one of its possible meanings (interpretations). In the other meanings it might be unconstitutional. Courts and the Supreme Court are supposed to comply with

2 Florczak-Wątor, Monika. Orzeczenia Trybunału Konstytucyjnego i ich skutki prawne. Poznan: Ars boni etaequi, 2006, pp. 94; Tulej, Małgorzata. Orzecznictwo interpretacyjne Trybunału Konstytucyjnego a reguly wykładni prawa. Warsaw: Difin, 2012, pp. 132; the judgement of the Tribunal of 5 January 1999 (K. 27/98, OTK ZU 1999/1/1).

3 Rousseau, Dominique. Sadownictwo konstytucyjne w Europie. Warsaw: Wydawnictwo Sejmowe, 1999, pp. 74.

4 Czeszejko-Sochacki, Zdzisław. Sądownictwo konstytucyjne na tle porównawczym. Warsaw: Biuro Trybunału Konstytucyjnego, 2003, pp. 409.

5 Białogłowski, Wojciech. Wznowienie postępowania w następstwie wydania przez TK wyroku interpretacyjnego. In Beratt, Maciej, Królikowski, Jakub, ZiółkowskI, Michał (eds). Skutki wyroków Trybunału Konstytucyjnego w sferze stosowania prawa. Studia i Materialy Trybunału Konstytucyjnego. Warsaw: Biuro Trybunału Konstytucyjnego, 2013, pp. 193; Czeszejko-Sochacki, Zdzisław. Sądownictwo..., supra note 4, pp. 411; Garlicki, Leszek. Uwagi o charakterze prawnym orzeczeń Trybunału Konstytucyjnego. In Trzciński, Janusz, Banaszak, Bogusław (eds). Studia nad prawem konstytucyjnym. Wroclaw: Wydawnictwo Uniwersytetu Wrocławskiego, 1997, pp. 91; Tulej, Małgorzata. Orzecznictwo..., supra note 2, pp. 125. 
the interpretation of the provision specified by the Tribunal. They should use the meaning of the provision that is in accordance with the constitution and avoid meanings that are unconstitutional ${ }^{6}$. Thus the Tribunal uses interpretative judgements in order not to annul the statute. Such judgements make this interpretation solid and force other authorities to use only it. Courts ought to interpret the provision in the same way as the Tribunal did in its judgement. The interpretative judgement is not supposed to remove variance and divergence in the interpretation of a provision. It is supposed to find such a meaning of the provision that complies with the constitution ${ }^{7}$.

\section{History}

The Constitutional Tribunal has been using the method of interpretation of laws in accordance with the constitution since the very beginning of its activity. However, the first interpretative judgement was issued in $1993^{8}$. The legal basis for this kind of judgments was Article 33a.1 of the Constitution of the Republic of Poland of $1952^{9}$. Pursuant to this provision the Tribunal was able to formulate universally binding interpretation of the laws (statutes). This competence was developed in two institutions: interpretative judgements and interpretative rulings. After the year 1994 a number of interpretative judgements rose significantly. Once the contemporary binding Constitution was established in 1997, the situation has not changed. On average the Tribunal used to issue 5 interpretative judgments per year. It changed after the reaction of the Supreme Court in 2009.

\section{Issue of the dispute and arguments}

After establishing the Constitution of 1997 the Supreme Court and other courts found that interpretive judgements of the Tribunal did not have a legal basis, because the contemporary Constitution did not contain any provision that would allow issuing this kinds of judgements and the previous Constitution of 1952 lost its binding force. The Tribunal and its supporters claim that replacing the basic act has changed nothing and that the Tribunal is still eligible to issue binding interpretative judgements.

Thus the dispute over interpretative judgements has turn into a dispute over authority between the Tribunal and the Supreme Court ${ }^{10}$. The problem is that there is no authority that would be able (had competence) to solve this problem. Both - the Tribunal and the Supreme Court - are parts of judicial power, are independent from other powers and authorities and have own specific compe-

6 Nowicki, Damian. Miejsce orzeczeń interpretacyjnych w orzecznictwie Trybunału Konstytucyjnego. Państwo i Prawo, 2012, vol. 10, pp. 9.

7 The judgment of the Tribunal of 11 December 2001 (SK 16/00, OTK ZU 2001/0/257).

8 The judgment of the Tribunal of 20 April 1993 (U 12/92, OTK ZU 1993/9).

9 Dz.U. 1952, no 33, item 232.

10 Tulej, Małgorzata. Orzecznictwo..., supra note 2, pp. 125. 
tences. However, their areas of activity sometimes overlap. Such a dispute can be resolved neither by the Tribunal nor the Supreme Court. The latter is not entitled to forbid the Tribunal to issue interpretative judgements and the Tribunal is not legitimated to force the Supreme Court to obey them ${ }^{11}$.

The dispute concerns the legitimation of the Tribunal to issue interpretative judgements and their binding force. In fact, the dispute consists of two problems ${ }^{12}$. As it has been stated above, the Tribunal and its supporters claim that the Tribunal is eligible to issue such judgements, they have binding force and the Supreme Court and other courts are supposed to obey and apply the meaning of a statutory provision expressed in the conclusion of the judgement of the Tribunal. The Supreme Court and its protagonists criticize this point of view. They maintain that the Tribunal has authority to interpret statutes and other provisions, but effects of its intellectual activity are not supposed to bind courts. Nowadays the Tribunal does not have a legal (constitutional) basis to settle a binding interpretation of statutes. Using this implied competence the Tribunal baselessly interferes in a legal activity of the Supreme Court. Moreover, opponents indicate that it is very difficult to specify legal effects of interpretative judgements. Typical Tribunal's decisions do not cause such problems. If the Tribunal finds that a statute conflicts with the Constitution, its judgement derogates the act. If the Tribunal decides that the statute is valid, the act remains as part of a legal system. It is stated in interpretative judgements that one of the meanings of a reviewed provision is valid/invalid, but the judgment does not result in withdrawing the whole provision. It remains in the system. This issue is connected with another problem. Pursuant to Article 190.4 of the Constitution 'A judgment of the Constitutional Tribunal on the non-conformity to the Constitution, an international agreement or statute, of a normative act on the basis of which a legally effective judgment of a court, a final administrative decision or settlement of other matters was issued, shall be a basis for reopening proceedings, or for quashing the decision or other settlement in a manner and on principles specified in provisions applicable to the given proceedings'. It is unknown if interpretative judgements can be such a decision. Laws that are subject of the judgment remain in the system without any change. It is claimed that such judgements in reality confirm legality of a controlled provision ${ }^{13}$ even if the judgments say that one of the possible meanings of the provision is invalid.

11 Gardocki, Lech. Problem tak zwanych wyroków interpretacyjnych Trybunału Konstytucyjnego. In Winczorek, Piotr (ed). Teoria i praktyka wykładni prawa, Warsaw: Liber, 2005, pp. 156, the resolution of the Supreme Court of 17 December 2009 (III PZP 2/09, OSNC 2010/7-8/97).

12 Dąbrowski, Marcin. Funkcje Trybunału Konstytucyjnego zwiąane z hierarchiczna kontrolq konstytucyjności prawa. Olsztyn: Wydawnictwo UWM, 2015, pp. 248.

13 Nowicki, Damian. Miejsce..., supra note 6, pp. 58-59; Kolasiński, Krzysztof. Wpływ orzecznictwa Trybunału Konstytucyjnego na orzecznictwo sądowe. In Rymarz, Ferdynand, Jankiewicz, Adam (eds). Trybunat Konstytucyjny. Ksiega XV - lecia. Warsaw: Biuro Trybunału Konstytucyjnego, 2001, pp. 147. 
The dispute generally divided scholars and lawyers into two parties: opponents and supporters. Supporters ${ }^{14}$ generally derive from the circles clustered around the Tribunal and constitutional lawyers. Opponents ${ }^{15}$ usually circle around the Supreme Court and lawyers who specialize in other branches of law.

Opponents of judgements claim that they do not have legal grounds. Article 190 of the Constitution indicates major types and consequences of judgments passed by the Tribunal. There is no interpretative judgement among them. Besides, Article 178.1 of the Constitution provides that judges are subject only to the Constitution and statutes. Accordingly, they are not bound by interpretative judgements. The Tribunal is obliged to obey Article 7 of the Constitution 'The organs of public authority shall function on the basis of, and within the limits of, the law'. It means that every action of any authority must be covered by law. Competences must not be implied ${ }^{16}$, which means that issuing interpretative judgements the Tribunal breaches its powers.

These judgements limit the judge's independence. This important principle is part of the concept of a democratic state. It is strengthened by Article 8 of the Constitution which provides that the provisions of the Constitution shall be applied directly. According to this regulation courts are entitled to resolve cases only on the grounds of the Constitution ${ }^{17}$. The court independence is a kind of guarantee which stabilizes judicature and ensures safety of the legal system. The Tribunal's interpretation of a reviewed provision should be part of legal justification of the judgement, not part of its conclusion. Without legal grounds the Tribunal moves argumentation to the conclusion which has universally binding force. Courts as well the Tribunal are entitled to construe provisions while adjudicating cases and applying laws, but it does not have any formal influence on decisions of other courts. The Tribunal and its interpretative judgements interfere in a judicial process of applying law despite the fact it does not have legal grounds for such immissions. The Tribunal does not exercise review over the activity of the Supreme Court and other courts. Thus, it is not entitled do give

14 Florczak-Wątor, Monika. Orzeczenia..., supra note 2, pp.101 et seq.; Garlicki, Leszek. Trybunał Konstytucyjny a sądownictwo. Przegląd Sądowy, 1998, vol. 1, pp. 18; Trzciński, Janusz. Orzeczenia interpretacyjne Trybunału Konstytucyjnego. Państwo i Prawo, 2002, vol. 1; Wiącek, Marcin. Glosa do uchwały SN z dnia 17 grudnia 2009 r. (Case III PZP 2/09). Przegląd Sejmowy, 2010, vol. 3.

15 Jaśkowska, Małgorzata. Skutki orzeczeń Trybunału Konstytucyjnego dla procesu stosowana prawa wobec zasady bezpośredniego stosowana konstytucji. In Skrzydło-Niżnik, Iwona (ed). Instytucje współczesnego prawa administracyjnego. Księga jubileuszowa prof. zw. dra hab. Józefa Filipka. Crakow: Wydawnictwo Uniwersytetu Jagiellońskiego, 2001, pp. 227 et seq; Józefowicz, Adam. Orzeczenia interpretacyjne Trybunału Konstytucyjnego. Państwo i Prawo, 1999, vol. 11; Pietrzykowski, Krzysztof. O tak zwanych „interpretacyjnych” wyrokach Trybunału Konstytucyjnego. Przeglad Sądowy, 2004, vol. 3.

16 Banaszak, Bogusław. Konstytucja Rzeczpospolitej Polskiej. Komentarz. Warsaw: C.H.Beck, 2009, pp. 58; the judgment of the Tribunal of 10 May 1994 (W 7/94, OTK ZU 1994/1/23).

17 The judgment of the Supreme Court of 26 September 2007 (III KK 206/07). 
instructions to courts how to construe statutes. Such guidelines restrict the independence of courts $^{18}$.

Furthermore, interpretative judgements stabilise invalid and constitutionally doubtful provisions. These judgements may be seen as an attempt to restore the Tribunal's competence to formulate universally binding interpretation of laws, but the contemporary binding Constitution has rejected this institution. Interpretive judgements may be helpful and useful for courts, but these judgments do not bind in the course of adjudicating cases. Interpretative judgements cause problems with the stability of the body of laws. Addressees of provisions that are covered with the judgement made by the Tribunal do not know what the real meaning of provisions is, because the judgement does not change the form and binding status of provisions, only its understanding ${ }^{19}$. Finally, interpretative judgements change (eliminate) a meaning or meanings of a provision. After issuing an interpretative judgement the substance of reviewed laws is different. It means that the Tribunal acts as a law creator $^{20}$. In the Polish law system courts and the Tribunal are not supposed to be legislators (establish provisions and norms).

Supporters of the Tribunal's conception of an interpretative judgement claim that these judgments arise from the essence of constitutional review. The Tribunal does not need to have a particular provision (norm) which would legitimize issuing such judgments. Conception of such judgments complies with major constitutional rules and principles such as the rule of law, separation of powers, sovereignty of the people. Arguments that are focused on lack of a legal basis of judgements are meaningless. Interpretative judgements have the same legal basis as others types of Tribunal judgements. They arise from the concept of a democratic state where the law system should be harmonized, consistent and does not contain any loopholes and contradicted provisions. It is said that this kind of judgements are an immanent part of constitutional review ${ }^{21}$. Thus the Tribunal's legitimacy to control the conformity legal acts to the Constitution also determines legitimacy to issue interpretative judgements. If the constitutional court is able to derogate a statute, then it is able construe it or to change its meaning. Besides, the Constitution does not forbid to issue a judgement that contains formally binding interpretation of a provision. Controlling legality of law acts is much more complicated and requires more sophisticated judgements.

18 PietrzykowskI, Krzysztof. O tak zwanych..., supra note 15, pp. 28.

19 Kustra, Aleksandra. Uchwała składu siedmiu sędziów Sądu Najwyższego - Izba Pracy, Ubezpieczeń Społecznych i Spraw Publicznych z dnia 17grudnia 2009 r., III PZP 2/09. Glosa. Orzecznictwo Sąów Polskich, 2010, vol. 10, pp. 721; Mikołajewicz, Jarosław. Orzeczenia zakresowe i interpretacyjne Trybunału Konstytucyjnego jako przejaw kryzysu legitymizacji legalnej. In ONISZCZUK, Jerzy (ed). Normatywność i kryzys. Jedność, czy różnorodność. Warsaw: Oficyna Wydawnicza Szkoły Głównej Handlowej, 2010, pp. 235.

20 Rousseau, Dominique. Sadownictwo..., supra note 3, pp. 73.

21 Tulej, Małgorzata. Orzecznictwo..., supra note 2, pp. 136. 
The Tribunal should not derogate a statute (provision) unless it is unavoidable. Interpretative judgements are an instrument which allows doing so. Interpretative judgements protect the functions and powers of chambers of the Parliament. Since laws (statutes and their provisions) are not annulled, the body of laws is stable. Moreover, there is no need to derogate a provision because one of its meanings is invalid, whereas the other possible meanings are correct. The Tribunal indicates proper interpretation, but courts are supposed to abide by it, and apply while adjudicating cases. Interpretative judgements do not involve the Parliament in a process of making amends (repairing) an invalid provision. Derogating a statute or its provision is always treated as disavowing effects of Parliament's work. It eliminates possible but unnecessary conflicts between the chambers and the Tribunal ${ }^{22}$. Such disputes always have a political character and weaken the position of participating parties. Using the formula of interpretative judgements the Tribunal fulfils two important functions. Firstly, unconstitutional norms are eliminated and will not be used by courts. Secondly, it makes a reviewed provision remain in the legal system with the Parliament's competence of establishing statutes not being violated. Furthermore, the idea of interpretative judgement is strongly supported by the presumption of constitutionality of legal acts. This rule demands an authority to protect the position of a legislator.

It is claimed that there is a serious difference between the interpretation of statutes made by courts and by the Tribuna ${ }^{23}$, because these institutions play different roles and fulfil different functions. The Tribunal does not apply the law in the same way courts do. The constitutional court is supposed to protect the legal system and the Constitution while courts implement the administration of justice. Both institutions construe provisions, but it is done to achieve different purposes. The Tribunal that interprets a statute does not interfere in independence of courts and does not abrogate functions of courts.

Supporters also claim that interpretative judgements are not an attempt to reconstruct the Tribunal's power to formulate universally binding interpretation of laws (statutes). Judgments arise from the interpretation of laws in accordance with the constitution. Both institutions (interpretative judgements) and universally binding interpretation were separated and developed apart.

Observing this dispute and presented arguments I think that there is no dialogue between courts and the Tribunal, only two monologues. Each party presents its point of view without listening to the opposing party. It looks a little like Order 227 issued on July 28, 1942 by Joseph Stalin 'No one steps back'. Joseph Stalin ordered the Red Army personnel to 'fight to the last drop of blood', virtually banned them from surrendering, and set out severe penalties for deserters. The dispute between the Tribunal and the Supreme Court seems to be very simi-

22 Florczak-Wątor, Monika. Orzeczenia..., supra note 2, pp. 93-103.

23 Trzciński, Janusz. Orzeczenia..., supra note 14, pp. 8. 
lar. Fight to the very end, no one steps back and costs do not matter. Nobody looks for a compromise.

\section{Decisions of the Supreme Court}

The Supreme Court generally accepts a standpoint that the Tribunal is the only authority which is entitled to control the constitutionality of legal acts, in particular, statutes ${ }^{24}$. Yet jurisdictions of the Supreme Court and other courts which referred to the interpretative judgements made the Tribunal were very unstable and various. It occurred especially at the beginning of the dispute.

The judgement of the Supreme Court dated 6 November $2003^{25}$ is an example of lack of acceptance of this kind of Tribunal's judgements. In the justification the Court claims that 'Law interpretation proclaimed by the Constitutional Tribunal does not have any binding force for courts.... Thus, courts are not supposed to apply the Tribunal's clarifications. The Supreme Court expressed a similar point of view in the judgement of 3 July $2003^{26}$, 'Such judgments [interpretativeM.D.] formally do not influence the application of law, because they do not have their legal base in constitutional provisions which would be strong enough' In this judgement of 3 July 2003 the Supreme Court also states that interpretation of provisions may bind courts because of strength of presented arguments, not because it has a legally binding character ${ }^{27}$. It means that courts should apply interpretations of the Tribunal if its arguments are convicting enough. Generally, in such situations decisions of lower courts depend on a judgement of the Supreme Court. If the Court accepts the Tribunal's interpretation, lower courts follow this statement. For instance, such a situation took place in 2001. The Tribunal gave an interpretative judgement on 4 November $2001^{28}$. In the judgment the Tribunal interpreted Article 417 of the Civil Code. The judgment and its interpretative conclusion were approved in the judgment of the Supreme Court of 8 January $2002^{29}$ and in several different judgements ${ }^{30}$.

24 E.g.: the jurisdiction of the Supreme Court of 18 September 2002 (III CKN 326/01); the judgement of Supreme Court of 30 October 2002 (V CKN 1456/00), the jurisdiction of the Supreme Court of 10 July 2008 (III CZP 63/08).

25 IV CKN 178/01.

26 III CZP 45/03.

27 A very similar statement is expressed in the Supreme Court judgment of 6 May 2003 (I CO 7/03, OSNC 2004/1/14).

28 SK 18/00, OTK ZU 2001/8/256.

29 I CKN 581/2002.

30 E.g.: judgment of the Supreme Court of 27 November 2002, I CKN 12/15; of 21 May 2003 IV CKN 178/01, of 9 October 2003, I CKN 158/02).

A similar situation took place in 2002. The Tribunal in the interpretative judgement of 18 November 2002 construes Article 4a of the Act of 16 November 1994 on Negotiative System of Fixing the Average Pay Growth in Corporate Entities and amending certain acts (Dz.U. 1995, no 1, item 2). The Supreme Court approved the Tribunal's judgement in its own judgment of 20 May 2004 (II PZP 7/04). 
Simultaneously, the Supreme Court gave judgments which approved of binding force of the Tribunal's interpretative judgements. For example, in the judgment of 4 July $2001^{31}$ the Supreme Court claims that interpretative judgements which confirm validity of legal acts have binding force and shall be applied by courts. In such situations courts are not supposed to refuse to apply the act because of its unconstitutionality which is found by courts despite the fact that the Tribunal's judgment is different.

Additionally, in a few judgements the Supreme Court claims that interpretative judgements which find unconstitutionality of one of the possible meaning of a reviewed provision cannot be a base for reopening proceedings and cases on the basis of Article 190.4 of the Constitution ${ }^{32}$. Nevertheless, in a few different cases the Supreme Courts adjudicates that interpretative judgements on the nonconformity to the Constitution shall not be a basis for reopening proceedings and cases ${ }^{33}$.

\section{End of the dispute - the ruling of the Supreme Court of 17 December 2009}

In general, the dispute was put to an end by the Supreme Court. Its ruling of 17 December $2009^{34}$ was a conclusive argument, but the Tribunal still sometimes passes interpretative judgements. The ruling was taken on the base of application prepared and brought by the Ombudsman. He took his action because of serious diversification of the Supreme Court's judgments which referred to the Tribunal's interpretative ones. In the ruling the Supreme Court adjudicates that interpretative judgements of the Tribunal on non-constitutionality of a particular meaning of a provision shall not constitute a basis for reopening processes and trials on the grounds of Article $401^{1}$ of the Code of Civil Procedure. The ruling has a status of a principle of law. In the justification the Court repeats arguments of the opponents of interpretative judgements. The interpretation of a provision indicated in the conclusion of the Tribunal's judgements does not have binding force and it is only part of justifications of the judgment. Furthermore, the Tribunal's judgement on non-constitutionality of one of the meanings of the provision does not derogate anything and does not cause any changes in the body of laws. In fact, such Tribunal's judgements act as judgments on compliance of a normative act with the Constitution. Thus, the Supreme Court decides to treat all types of interpretative judgements as judgements that confirm validity of normative acts.

31 III ZP 12/01.

32 The judgement of the Supreme Court of 6 May 2003 (I CO 7/03 (OSNC nr 12004/1/14).

33 E.g. three judgements of the Supreme Court of 20 November 2008 (III UO 6/08, III UO $10 / 08$ and III UO 12/08) and the verdict of 11 March 2009 (II UZ 2/09).

34 III PZP 2/09. 
As it has been pointed out above, the ruling has a status of a principle of law. It means that this act binds the Supreme Court in different cases. Formally, the ruling does not bind lower courts ${ }^{35}$, but it is an important guideline and it does not happen that courts give judgements that contradict the Supreme Court's rulings. For courts the Supreme Court has a bigger authority than the Tribunal. It stems from the fact that the administration of justice in the Republic of Poland is implemented by the Supreme Court. Finally, during the dispute courts advocate the side of the Supreme Court. This was the second major argument which allowed abrogating the dispute. Following this act all lower courts have the same approach to interpretative judgements. Courts are vital authorities which enforce the Tribunal's judgments, because courts are their major addressees. If courts do not implement guidelines which arise from interpretative judgements, these judgements become meaningless. The Supreme Court's ruling and analogous decisions of common courts have weakened the position, functions, and role of interpretative judgements.

The ruling does not have any influence on the activity of the Tribunal. This authority is not bound by courts' judgments. Exercising their office, judges of the Constitutional Tribunal shall be independent and subject only to the Constitution (Article 195.1 of the Constitution). The Tribunal still has an ability to issue such a judgement. The Supreme Court's ruling has not changed competences of the Tribunal. However, the ruling has reduced the sense of passing them and their effectiveness. Hence, because of the ruling the Tribunal has reduced the number of interpretative judgements it issues. In a period of time between the date when the Constitution of 1997 came into force (17.10.1997) and the date of issuing the ruling (17.12.2009) the Tribunal passed 49 interpretative judgements whereas between the date 17.12.2009 and the end of the year 2015 the Tribunal issued only 15 such judgments, which means that the Tribunal has limited the number yet has not finished issuing interpretative judgements.

The ruling is strongly criticized by supporters of interpretative judgements. Supporters introduce the same arguments, but their animadversion is directed generally against the Supreme Courts' ruling of $2009^{36}$.

\section{Summary}

One of the causes of the dispute is the fact that the Tribunal often borrows some institutions from foreign systems without deeper reflection whether they really suit the Polish constitutional reality. Judgments of the German Federal Constitutional Court has had a significant influence on Polish interpretive judgements $\mathrm{s}^{37}$. Such solutions do not always fit into the body of laws and authori-

35 Tulej, Małgorzata. Orzecznictwo..., supra note 2, pp.168.

36 E.g.: Białogłowski, Wojciech. Wznowienie..., supra note 5, pp.189 et seq.; Wiącek, Marcin. Glosa..., supra note 14, pp.153.

37 Czeszejko-Sochacki, Zdzisław. Sądownictwo..., supra note 4, pp. 409. 
ties which apply law have problems with accepting such institutions. Most interpretative judgements can be replaced by different types of Tribunal's judgements. In these situations common courts will refuse to apply Tribunal's interpretative ones.

The Tribunal is entitled to construe provisions under review; however, it is unable to force courts to use its understanding of provisions. Thus such interpretation should not be part of a conclusion. Despite the fact that it is placed in conclusion I think that such a construction does not have universally binding force. Only strong and important arguments may encourage courts to accept the meaning of provisions determined by the Tribunal. I am not entirely sure if such judgments are always really necessary. I think that in some complicated situations interpretative judgements may be allowable ${ }^{38}$. It will take place in particular when the other types of the Tribunal's judgements are not suitable and effective enough; nonetheless, it must be said that such a situation is very rare. A justification of the judgement should be very precise and convincing. In such a case the Supreme Court and other courts would accept this kind of judgement and its consequences.

\section{References (alphabetical order)}

Banaszak, Bogusław. Konstytucja Rzeczpospolitej Polskiej. Komentarz. Warsaw: C.H.Beck, 2009.

Białogłowski, Wojciech. Wznowienie postępowania w następstwie wydania przez TK wyroku interpretacyjnego. In Beratt, Maciej, Królikowski, Jakub, ZiółkowskI, Michał (eds). Skutki wyroków Trybunału Konstytucyjnego w sferze stosowania prawa. Studia i Materiały Trybunału Konstytucyjnego. Warsaw: Biuro Trybunału Konstytucyjnego, 2013.

Czeszejko-Sochacki, Zdzisław. Sąownictwo konstytucyjne na tle porównawczym. Warsaw: Biuro Trybunału Konstytucyjnego, 2003.

Dąbrowski, Marcin. Funkcje Trybunału Konstytucyjnego zwiąane z hierarchiczna kontrola konstytucyjności prawa. Olsztyn: Wydawnictwo UWM, 2015.

Florczak-Wątor, Monika. Orzeczenia Trybunału Konstytucyjnego i ich skutki prawne. Poznan: Ars boni etaequi, 2006.

Gardocki, Lech. Problem tak zwanych wyroków interpretacyjnych Trybunału Konstytucyjnego. In Winczorek, Piotr (ed). Teoria i praktyka wykładni prawa, Warsaw: Liber, 2005.

Garlicki, Leszek. Uwagi o charakterze prawnym orzeczeń Trybunału Konstytucyjnego. In Trzciński, Janusz, Banaszak, Bogusław (eds). Studia nad prawem konstytucyjnym. Wroclaw: Wydawnictwo Uniwersytetu Wrocławskiego, 1997.

Garlicki, Leszek. Trybunał Konstytucyjny a sądownictwo. Przegląd Sądowy, 1998.

Jaśkowska, Małgorzata. Skutki orzeczeń Trybunału Konstytucyjnego dla procesu stosowana prawa wobec zasady bezpośredniego stosowana konstytucji. In Skrzydło-Niżnik, Iwona (ed). Instytucje współczesnego prawa administracyjnego. Księga jubileuszowa prof. zw. dra hab. Józefa Filipka. Crakow: Wydawnictwo Uniwersytetu Jagiellońskiego, 2001.

38 Nowicki, Damian, Miejsce..., supra note 6, pp.60. 
Józefowicz, Adam. Orzeczenia interpretacyjne Trybunału Konstytucyjnego. Państwo $i$ Prawo, 1999, vol. 11.

Kolasiński, Krzysztof. Wpływ orzecznictwa Trybunału Konstytucyjnego na orzecznictwo sądowe. In Rymarz, Ferdynand, Jankiewicz, Adam (eds). Trybunał Konstytucyjny. Księga XV - lecia. Warsaw: Biuro Trybunału Konstytucyjnego, 2001.

Kustra, Aleksandra. Uchwała składu siedmiu sędziów Sądu Najwyższego - Izba Pracy, Ubezpieczeń Społecznych i Spraw Publicznych z dnia 17grudnia 2009 r., III PZP 2/09. Glosa. Orzecznictwo Sąów Polskich, 2010, vol. 10.

Mikołajewicz, Jarosław. Orzeczenia zakresowe i interpretacyjne Trybunału Konstytucyjnego jako przejaw kryzysu legitymizacji legalnej. In ONISZCZUK, Jerzy (ed). Normatywność i kryzys. Jedność, czy różnorodność. Warsaw: Oficyna Wydawnicza Szkoły Głównej Handlowej, 2010.

Morawski, Lech. Zasady wykładni prawa. Torun: Dom Organizatora TNOiK, 2010.

Nowicki, Damian. Miejsce orzeczeń interpretacyjnych w orzecznictwie Trybunału Konstytucyjnego. Państwo i Prawo, 2012, vol. 10.

Pietrzykowski, Krzysztof. O tak zwanych „interpretacyjnych” wyrokach Trybunału Konstytucyjnego. Przeglad Sądowy, 2004, vol. 3.

Rousseau, Dominique. Sadownictwo konstytucyjne w Europie. Warsaw: Wydawnictwo Sejmowe, 1999.

Trzciński, Janusz. Orzeczenia interpretacyjne Trybunału Konstytucyjnego. Państwo $i$ Prawo, 2002, vol. 1.

Tulej, Małgorzata. Orzecznictwo interpretacyjne Trybunału Konstytucyjnego a reguły wykładni prawa. Warsaw: Difin, 2012.

Wiącek, Marcin. Glosa do uchwały SN z dnia 17 grudnia 2009 r. (Case III PZP 2/09). Przegląd Sejmowy, 2010, vol. 3. 